\title{
The Spread of Malaria to Southern Europe in Antiquity: New Approaches to Old Problems
}

\author{
ROBERT SALLARES, ABIGAIL BOUWMAN \\ and CECILIA ANDERUNG*
}

\section{Introduction}

The discoveries in the late nineteenth century that malaria is caused by protozoan parasites, which are transmitted by mosquitoes, quickly led to intense speculation about its history in antiquity. The historiography of malaria has passed through three distinct phases during the last hundred years or so. The first generation of historians to consider the effects of malaria did exaggerate its significance in some respects. The argument by W H S Jones that the Greek doctrine of fevers was based on malaria was generally and rightly accepted. However, it is not surprising that his view that malaria was a major reason for the degeneration of the moral character of the ancient Greeks attracted little sympathy. ${ }^{1}$ The eradication of malaria from southern Europe in the 1930s and 1940s contributed to a decline of interest in the subject. Subsequently medical historians and even professional malariologists tended to minimize the historical significance of malaria. ${ }^{2}$ The revisionist tendencies of this second phase of research led to attempts to reassess some of the details of the evidence upon which Jones had relied. For example, Leonard Bruce-Chwatt and Julian de Zulueta rejected Jones's belief that Plasmodium falciparum, the most dangerous of the four species of human malaria, was already active in Greece in the fifth century BC. They suggested that it started to spread in southern Europe only during the time of the Roman Empire and attributed all the references to intermittent tertian fevers in Hippocratic texts dating to the fifth and fourth centuries BC to the less virulent $P$. vivax. ${ }^{3}$ Although the literature produced during this second phase of scholarship was in many ways more sophisticated, it still suffered from some of the same weaknesses; in particular, analysis proceeded in a purely qualitative manner, without any consideration of the effects of malaria on historical human populations in quantitative terms. A second weakness was a tendency to make generalizations covering the whole of Mediterranean Europe. Since many types of mosquito are

\footnotetext{
* Robert Sallares, MA; PhD, Dept of Biomolecular Sciences, UMIST, PO Box 88, Manchester, M60 1QD, United Kingdom (e-mail: rsallares@aol.com); Abigail Bouwman, MSc, PhD, Dept of Biomolecular Sciences, UMIST; Cecilia Anderung, MSc, Dept of Evolution, Genomics and Systematics, EBC, Uppsala University, Sweden.

We wish to thank David Soren for providing the photos of Lugnano and the bones.

${ }^{1} \mathrm{~W}$ H S Jones, Malaria, a neglected factor in the history of Greece and Rome, Cambridge University
}

Press, 1907, and Malaria and Greek history, Manchester University Press, 1909, pp. 97-102, cf. N Toscanelli, La malaria nell'antichità e la fine degli Etruschi, Milan, Hoepli, 1927; A Celli, The history of malaria in the Roman Campagna from ancient times, London, Bale \& Danielsson, 1933.

${ }^{2}$ For example, J Ruffié and J-C Sournia, Les épidémies dans l' histoire de l'homme: essai d'anthropologie médicale, Paris, Flammarion, 1984, p. 209.

${ }^{3}$ L Bruce-Chwatt and $\mathrm{J}$ de Zulueta, The rise and fall of malaria in Europe: a historico-epidemiological study, Oxford University Press, 1980, pp. 18-25. 


\section{Robert Sallares, Abigail Bouwman and Cecilia Anderung}

incapable of transmitting malaria to humans, mosquito breeding sites do not occur everywhere, and many mosquitoes do not fly further than a few hundred yards from their breeding sites, malaria can only be really understood by micro-analyses, conducted at a very local level, of geography, hydrology, climate, competition between different species of mosquito for breeding sites, and human activities.

Some recent studies, opening up a third wave of research, have focused on the effects of malaria on historical European populations in quantitative terms. ${ }^{4}$ These studies have conclusively demonstrated that malaria did have severe effects in terms of both morbidity and mortality on human populations in early modern Europe, but only within strictly circumscribed geographical areas. Malaria did not occur everywhere. Consequently, it is now possible to move towards a modern synthesis which affirms by analogy (given the scarcity of quantifiable demographic data from the ancient world) that malaria did have considerable effects in Mediterranean Europe in antiquity - killing or debilitating people to the extent that it altered the age structure of human populations, as well as changing human settlement patterns and influencing the nature of agricultural systems-but usually only at a localized level. The effects of malaria on human populations and societies in Mediterranean Europe during the time of the Roman Empire are now well understood. ${ }^{5}$ However, the debate about the time of introduction of $P$. falciparum to southern Europe and indeed the date of its origin as a specifically human parasite are still very much matters of controversy. The main purpose of this article is to consider some new approaches, some new evidence, and present a new hypothesis about the early history of malaria in southern Europe.

\section{Research in Molecular Evolution}

Comparative analysis of the genomes or complete DNA sequences of pathogenic microorganisms has introduced a new way of studying the evolution of human pathogens. Comparisons of $18 \mathrm{~S}$ ribosomal DNA gene sequences suggest that the divergence of $P$. falciparum from its only known close relative $P$. reichenowi, a parasite of chimpanzees, ran parallel to the divergence of hominids from chimpanzees, approximately five to ten million years ago. This is an example of parasite:host co-speciation. In contrast, the other three species of human malaria ( $P$. vivax, $P$. malariae, $P$. ovale) were lateral transfers from other primates to humans. ${ }^{6}$ However, there is intense controversy about the more recent molecular evolution of $P$. falciparum. One controversial hypothesis claims that all currently existing $P$. falciparum populations are descended from a most recent common ancestor (MRCA) which lived only a few thousand years ago during the Neolithic period. ${ }^{7}$ Other

\footnotetext{
${ }^{4} \mathrm{~L}$ del Panta, Malaria e regime demografico: la Maremma grossetana nell'ottocento preunitario, Messina, Università degli Studi di Messina, 1989, on Grosseto in central Italy; M Dobson, Contours of death and disease in early modern England, Cambridge University Press, 1997, on the Kent and Essex marsh parishes.

${ }^{5}$ R Sallares, Malaria and Rome: a history of malaria in ancient Italy, Oxford University Press, 2002, gives much more bibliography on the questions considered in this paper.
}

\footnotetext{
${ }^{6} \mathrm{P}$. ovale is not considered any further in this paper since it was never common in Mediterranean countries.

${ }^{7}$ S M Rich, M C Licht, R R Hudson, and F J Ayala, 'Malaria's Eve: evidence of a recent population bottleneck throughout the world populations of Plasmodium falciparum', Proc. Natl. Acad. Sci. USA, 1998, 95: 4425-30; S K Volkman, A E Barry, E J Lyons, K Nielsen, S Thomas, et al. 'Recent origin of Plasmodium falciparum from a single progenitor', Science, 2001, 293: 482-4.
} 


\section{The Spread of Malaria to Southern Europe in Antiquity}

scientists insist that $P$. falciparum has maintained a large effective population size with a high degree of genetic diversity for several hundred thousand years. ${ }^{8}$ Such divergent conclusions are possible because different scientists use different datasets and different methods for analysing the molecular data, which are in any case often difficult to date.

The most recent major study has synthesized these two polar views, concluding that the MRCA of $P$. falciparum is approaching 100,000 years old, although it has undergone a major population expansion within the last 10,000 years. ${ }^{9}$ Consequently the view adopted here is that $P$. falciparum is indeed a very ancient human parasite. Mario Coluzzi has cogently argued that its evolution as a human parasite is intricately bound up with the evolution of its most important and efficient vector in tropical Africa today, the mosquito species complex Anopheles gambiae. Since the forest ecotype is the oldest ecotype of A. gambiae, highly anthropophilic behaviour probably evolved in a closed forest environment in which the mosquitoes had few other large animals apart from humans to bite, rather than on open grasslands with a large variety of alternative prey. ${ }^{10}$ This is a highly plausible hypothesis, but the date at which humans entered the African rain forests then becomes a critical question. The current trend in research on human evolution is to stress that early hominids lived in environments which included some forests, not in completely open grasslands, and it is now known that early hominids were present in West Africa as well as East Africa as early as six million years ago. Moreover, recent archaeological research indicates that human huntergatherer populations have been continuously present in rain forest environments for a very long time. ${ }^{11}$ As a result, the association in tropical Africa between the forest ecotype of A. gambiae and Homo sapiens need not be as recent as the Holocene period, but could easily be much older and involve earlier species of hominids. Consequently, the hypothesis about the role of $A$. gambiae does not necessarily contradict the results of the molecular studies of malarial DNA which suggest that $P$. falciparum is a very ancient organism. The Holocene population expansion of $P$. falciparum in Africa would have been facilitated by the evolution of other ecotypes of A. gambiae from its original forest ecotype. The MRCA approximately 100,000 years ago is probably associated with the expansion of early modern humans. It was part of a malaria population which preyed on the human population to which "mitochondrial Eve", the ancestor of all currently existing human mitochondrial genotypes, belonged.

\footnotetext{
${ }^{8}$ A Hughes and F Verra, 'Very large long-term effective population size in the virulent human malaria parasite Plasmodium falciparum', Proc. R. Soc. Lond., 2001, B268: 1855-60; A Hughes and F Verra, 'Extensive polymorphism and ancient origin of Plasmodium falciparum', Trends in Parasitology, 2002, 18: 348-51; J Mu, J Duan, K D Makova, D Joy, C Huynh, et al., 'Chromosome-wide SNPs reveal an ancient origin for Plasmodium falciparum, Nature, 2002, 418: 323-6; D Forsdyke, 'Selective pressures that decrease synonymous mutations in Plasmodium falciparum', Trends in Parasitology, 2002, 18: 411-17.
}

${ }^{9}$ D A Joy, X Feng, J Mu, T Furuya, $\mathrm{K}$ Chotivanich, et al. 'Early origin and recent expansion of Plasmodium falciparum', Science, 2003, 300: 318-21.

${ }^{10}$ M Coluzzi, A Sabatini, A della Torre, M Di Deco, and V Petrarca, 'A polytene chromosome analysis of the Anopheles gambiae species complex', Science, 2002, 298: 1415-18.

${ }^{11}$ A survey of recent work in this field is provided by J Mercader (ed.), Under the canopy: the archaeology of tropical rain forests, Piscataway, NJ, Rutgers University Press, 2002. 
Ancient History

In the light of the uncertainties generated by current scientific research on the molecular evolution of malaria, it is still well worth considering the alternative way of exploring the early history of human malaria, namely working from the present as far back as possible using the evidence of historical documentary sources and archaeological materials. It is very likely that all species of human malaria (temperature-dependent diseases) and their vector mosquitoes were absent from Europe during the Quaternary Ice Ages. ${ }^{12}$ Nevertheless, there are plenty of references to the intermittent fevers characteristic of malaria in ancient literature such as the works of the Hippocratic Corpus in Greece in the fourth and fifth centuries BC, in ancient Indian texts (difficult to date), and in Chinese literature of the first millennium BC. ${ }^{13}$ These accounts leave no doubt whatsoever that benign tertian fever (caused by $P$. vivax) and quartan fever (caused by $P$. malariae) were endemic in the Old World from Greece to as far as India and China by $500 \mathrm{BC}$. Evidently these types of human malaria arrived in Greece some time between the end of the last Ice Age and 500 BC.

The history of $P$. falciparum (responsible for malignant tertian fever) is even more problematic, as has already been noted. It is generally agreed that it evolved in tropical Africa. ${ }^{14}$ Nevertheless, the earliest direct evidence for its history comes from Europe. The Roman author Celsus, writing during the reign of the emperor Tiberius in the first half of the first century AD, differentiated the clinical symptoms of semitertian fever from tertian fever in an account whose accuracy as a description of the differences between falciparum and vivax malaria has been recognized since the time of Ettore Marchiafava and Angelo Celli, the first scientists to identify falciparum parasites under the microscope, in 1889.

There are two types of tertian fever. The first type begins and finishes in the same manner as quartan fever. Its characteristic feature is that it disappears for one complete day and returns on the third day. The second type is much more dangerous. It too recurs on the third day. However, out of the forty-eight hours, the paroxysm lasts for almost thirty-six hours (sometimes more or less), and there is no total cessation during the remission, although it becomes less severe. Most doctors call this type of fever semitertian. ${ }^{15}$

Marchiafava described the text of Celsus as follows: "the clearest and most exact description of the two clinical types of tertian fevers are to be found in the works of Celsus". ${ }^{16}$ There are two important points to note here. Firstly, Celsus regarded all types of intermittent

\footnotetext{
${ }^{12}$ Bruce-Chwatt and de Zulueta, op. cit., note 3 above, pp. 9-11.

${ }^{13}$ For example, Hippocrates, Epidemiae, I.6, I.24, III.12, De aere, aquis, et locis, X-XII, Oeuvres complètes d' Hippocrate, ed. E Littré, Paris, J-B Baillière, 1839-61; KZysk, Religious healing in the Veda: with translations and annotations of medical hymns from the Rigveda and the Atharvaveda and renderings from the corresponding ritual texts, Philadelphia, Transactions of the American Philosophical Society, 1985, vol. 75, pt.7, pp. 34-44; L Dong, MXi, and F Thann, Les maux épidémiques dans l'empire chinois, Paris, L'Harmattan, 1996, pp. 95-6.

${ }^{14}$ D J Conway, C Fanello, J M Lloyd, B Al-Joubori, A Baloch, et al., 'Origin of Plasmodium falciparum
}

malaria is traced by mitochondrial DNA', Mol. Biochem. Parasitol., 2000, 111: 163-71.

${ }^{15}$ Celsus, De medicina, III.3.2: "tertianarum vero duo genera sunt. Alterum eodem modo, quo quartana, et incipiens et desinens, illo tantum interposito discrimine, quod unum diem praestat integrum, tertio redit. Alterum longe perniciosius, quod tertio quidem die revertitur, ex quadraginta et octo horis fere triginta et sex per accessionem occupat (interdum etiam vel minus vel plus), neque ex toto in remissione desistit, sed tantum levius est. Id genus plerique medici i $\mu \iota \tau \rho \iota \tau a \hat{i} v$ appellant."

${ }^{16}$ E Marchiafava and A Bignami, On summerautumn malarial fevers, transl. J Thompson, London, New Sydenham Society, 1894, pp. 231-2. 


\section{The Spread of Malaria to Southern Europe in Antiquity}

fevers, including what he called semitertian fever, as very widespread and common in his own time. ${ }^{17}$ Falciparum malaria was not a rare disease in the Roman world in the early first century AD. Secondly, although there was explicit discussion in antiquity of the possibility of new diseases arising, there is no indication whatsoever that Celsus (or any other ancient author) regarded falciparum malaria (or any other type of malaria) as a new disease. ${ }^{18}$ On the contrary, by using the Greek form of the word "semitertian", he recalled the earlier Hippocratic texts which also mention this type of fever. It was explicitly observed by another Roman author, Quintus Serenus, that the Romans had not coined a Latin name of their own for the disease, borrowing the Greek expression instead. ${ }^{19}$ This suggests that the disease was known in Greece before it became endemic in central Italy. The semitertian fevers described by Celsus are indeed mentioned in the Hippocratic Epidemics, for example in the second "constitution" (description of a particular set of atmospheric conditions thought to be responsible for disease) on the island of Thasos in northern Greece. The account of the first "constitution" at Thasos offers a one sentence definition of semitertian fever which is perfectly compatible with the statements of Celsus. ${ }^{20} \mathrm{We}$ are also given the important detail that patients suffering from semitertian fevers in the autumn frequently ended up in a coma. ${ }^{21}$ Cerebral malaria is a major syndrome of falciparum malaria, which is not caused by the other species of human malaria. This syndrome was also noticed later in antiquity, for instance by Archigenes of Apamea c.100 AD, as cited by Aetius of Amida. ${ }^{22}$ The uneven distribution of extant classical Greek literature, which mostly originates from Athens (never a hotspot for malaria), creates various problems, which cannot be discussed in detail here, regarding the prevalence of malaria across classical Greece as a whole. Nevertheless, it is clear that semitertian fevers, like other intermittent fevers, were common in at least some localities in northern Greece in the fifth century BC. ${ }^{23}$ The second "constitution"

Bruce-Chwatt and de Zulueta, op. cit., note 3 above, pp. 19, 89, accepted Celsus' evidence but incorrectly dated it to the second century AD. This is symptomatic of an unwarranted general tendency on the part of these authors to shorten the chronology for the spread of falciparum malaria in antiquity. The identification of semitertian fever in Celsus was also accepted by $\mathrm{G}$ Corbellini and L Merzagora, La malaria tra passato e presente: storia e luoghi della malattia in Italia, Rome, Università di Roma "La Sapienza", 1998, p. 14.

${ }^{17}$ Celsus, De medicina, III.3.1.

${ }^{18}$ Plutarch, Moralia, VIII.9.731b-734c, and Pliny, Historia naturalis, XXVI.1-9, both discussed leprosy as a new disease in Hellenistic and Roman times.

${ }^{19}$ Quintus Serenus, Liber medicinalis, 51.932-4, ed. R Pépin, Paris, Presses Universitaires de France, 1950.

${ }^{20}$ Hippocrates Epidemiae, I.2, op. cit., note 13

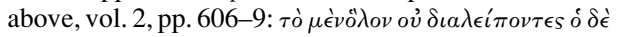

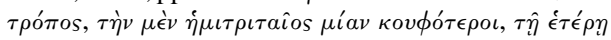
$\dot{\epsilon} \pi \iota \pi \alpha \rho \rho \xi v \nu o ́ \mu \epsilon \nu o \iota$. On the question, raised by

Bruce-Chwatt and de Zulueta, op. cit., note 3 above, p. 18 , of the association in the Hippocratic texts of semitertian fever with consumption (tuberculosis), see Sallares, op. cit., note 5 above, pp. 136-9.

${ }^{21}$ Hippocrates, op. cit., note 13 above, pp. 624-5:

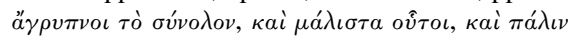
$\kappa \omega \mu \alpha \tau \omega \dot{\delta} \epsilon \epsilon s$. Julian de Zulueta's argument (mentioned by Corbellini and Merzagora, op. cit., note 16 above, p. 22), that sufferers from semitertian fever died too slowly for falciparum malaria to have been the cause, does not take into account the likelihood, discussed below in this article, that by the fifth century BC at least some populations in northern Greece already had a high frequency of human genetic mutations conferring some resistance to malaria. M Grmek, Diseases in the ancient Greek world, Baltimore, Johns Hopkins University Press, 1989, p. 281, accepted the identi- fication of falciparum malaria in the Hippocratic texts.

${ }^{22}$ Aetius of Amida, Libri medicinales, VI.3.

${ }^{23}$ For the problem of whether Macedonia was severely affected by malaria during the time of its rise to power under Philip and Alexander the Great in the fourth century BC, see E Borza 'Some observations on malaria and the ecology of central Macedonia in antiquity', Am. J. Ancient Hist., 1979, 4: 102-24. 


\section{Robert Sallares, Abigail Bouwman and Cecilia Anderung}

states that many people on Thasos were affected by semitertian fevers. ${ }^{24}$ The details about semitertian fever given in the Hippocratic texts are congruent both with Celsus' description and with modern knowledge of falciparum malaria. There is no evidence that the Greek word changed its meaning between the fifth century BC and the first century AD. Consequently, there is no good reason for not accepting that falciparum malaria was well known and common in at least some parts of Greece by the fifth century BC. The Hippocratic texts simply set a terminus ante quem for its appearance, since there is a scarcity of relevant earlier literature. ${ }^{25}$ Indeed, as will be seen later, there is another, completely different, type of argument which suggests that it was active in Greece well before the fifth century $\mathrm{BC}$.

However, a rather different picture emerges for Italy. One can discern three stages in the northwards spread of malaria in Italy (Figure 1). Firstly, literary sources suggest that it was already active in Sicily by the fifth century BC, when it was probably responsible for the epidemic which affected the Athenian army outside Syracuse during the Peloponnesian War, as Mirko Grmek once argued. ${ }^{26}$ Recent research on the physical environment of the territory of Syracuse has concluded that the area of marshland near the city was much larger in antiquity than it was in early modern times. ${ }^{27}$ This strengthens Grmek's arguments by showing that the natural environment around Syracuse was indeed highly favourable for malaria 2500 years ago. Similarly, numerous Greek colonies were established along the coasts of southern Italy c. 800-600 BC in regions that later suffered from intense malaria. Paestum in Campania, where famous Greek temples were constructed in the sixth and fifth centuries $\mathrm{BC}$, is one well known example. Later on the city declined because of neighbouring marshes which became unhealthy, as Strabo records in the first century BC. $^{28}$

The spread of malaria in western central Italy (the second stage of its spread in that country) seems to have been mainly a phenomenon of the period c. 400-100 BC. In the archaic and early classical periods, up to $c .400 \mathrm{BC}$, Etruscan cities such as Vulci and Vetulonia flourished in the Maremma, the coastal region of Tuscany, which was described as pestilential by Pliny the Younger in the first century AD. ${ }^{29}$ Vulci occupies a lowland site in the Maremma in an area where there was intense malaria in the early modern period. The archaeological remains, particularly the large numbers of imported Greek vases, testify to prosperity in the archaic period, while the famous wall paintings of the François tomb record contacts with Rome. It has even been suggested that the place name "Vulci" signified "prosperous place" in the ancient Etruscan language. ${ }^{30}$ It is difficult to believe that there

\footnotetext{
${ }^{24}$ Hippocrates, op. cit., note 13 above, pp. 618-9: í $\mu \iota \tau \rho \iota \tau \alpha \hat{\imath} о \iota, \tau \rho \iota \tau \alpha \hat{\imath} о \iota, \alpha \dot{\alpha} \kappa \iota ß \hat{\epsilon}_{\epsilon S}$,

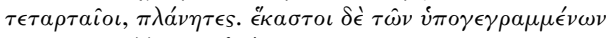

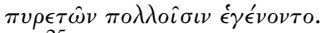

${ }^{25}$ This is a better approach to the problem than assuming, as W H S Jones (op. cit., note 1 above, p. 76) did, that the silence of very scarce earlier sources proves that malaria was unknown in Attica until c. 430 BC.

${ }^{26} \mathrm{M}$ Grmek, 'Les ruses de guerre biologiques dans l'antiquité', Revue des Études Grecques, 1979, 92: 141-63, on pp. 150-61.
}

\author{
${ }^{27} \mathrm{R}$ Mirisola and L Polacco, Contributi alla \\ paleogeografia di Siracusa e del territorio siracusano \\ (VIII-V sec. a.C.), Memorie, Classe di Scienze Morali, \\ Lettere ed Arti, vol. 66, Venice, Istituto Veneto di \\ Scienze, Lettere ed Arti, 1996, pp. 9-34. \\ ${ }^{28}$ Strabo, Geographia, V.4.13.251C. \\ ${ }^{29}$ Pliny the Younger, Epistolae, V.6.2. \\ ${ }^{30} \mathrm{G}$ Facchetti, 'Qualche osservazione sulla lingua \\ minoica', Kadmos 2001, 40: 1-38, on p. 14.
}


The Spread of Malaria to Southern Europe in Antiquity

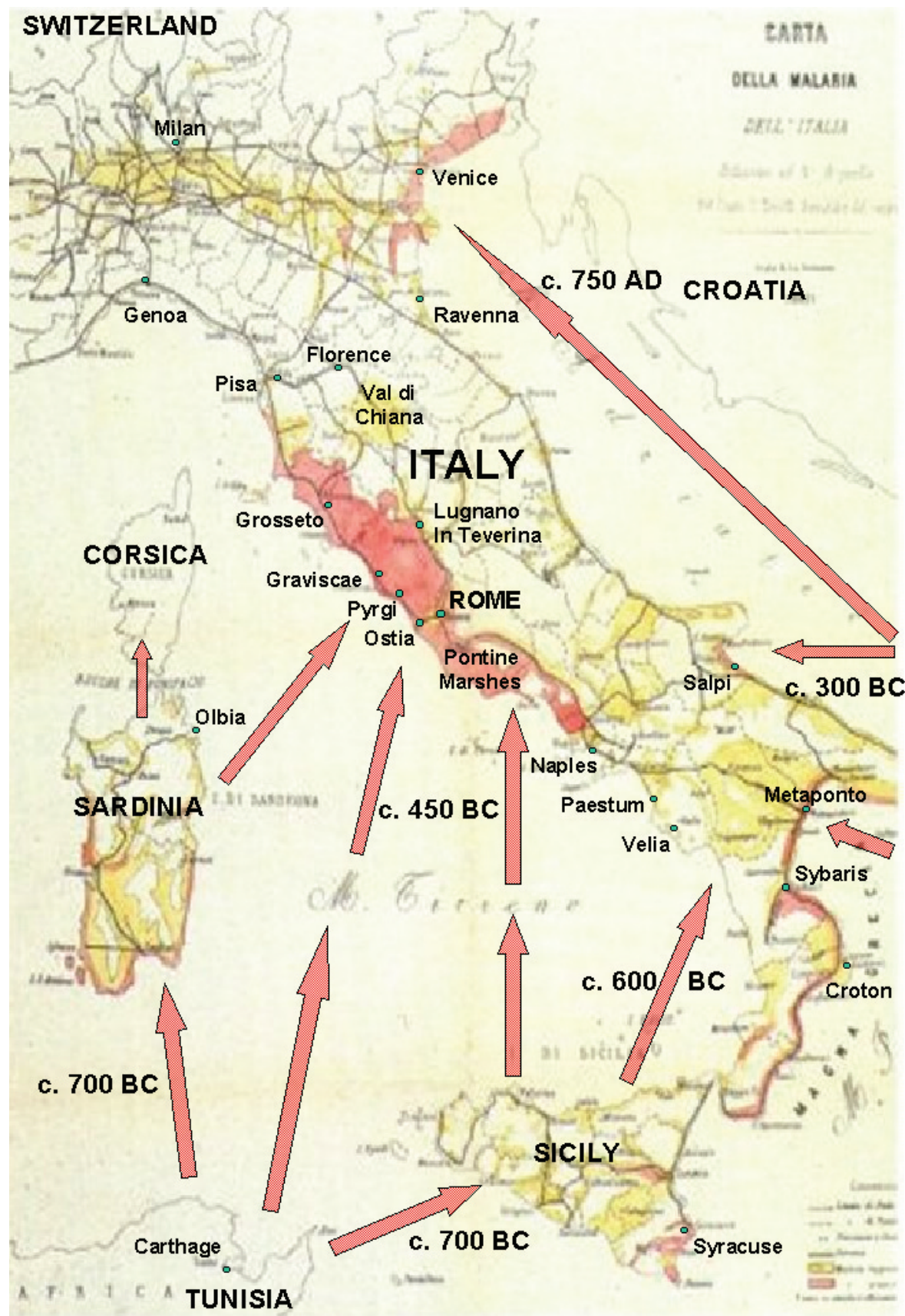

Figure 1: Map of Italy, adapted from Luigi Torelli's map of the distribution of malaria in Italy published in 1882. The arrows show the spread of the disease in the past, with very approximate dates (TAQs), following its vector mosquitoes. 


\section{Robert Sallares, Abigail Bouwman and Cecilia Anderung}

was endemic malaria there during the city's period of prosperity, but it is barely mentioned in literary sources dating to the first and second centuries BC, when a significant quantity of written evidence first becomes available from Rome. Consequently it is likely that malaria, and by implication its mosquito vectors, spread widely along the coast of Tuscany in the third and second centuries BC. The earliest record of endemic malaria at a specific location in this region by a contemporary author, Cato the Elder, relates to Graviscae, the port of the Etruscan city of Tarquinia, $c .150 \mathrm{BC}$, but this mention, of course, only provides a terminus ante quem for its arrival. ${ }^{31}$ Both the malaria of Graviscae and the mosquitoes that transmitted it probably arrived by sea, either from Sardinia or Sicily or directly from North Africa. In the late second century BC Asclepiades of Bithynia described severe intermittent fevers with the cerebral symptoms frequently found in falciparum malaria as common in the city of Rome itself, and Galen repeated this opinion in the second century AD. ${ }^{32}$ There is no doubt that the countryside around Rome had become a zone where malaria was endemic by the time of the Roman Empire. Mike McCormick has recently demonstrated by a study of papal correspondence that the seasonal pattern of travel that is well known for the early modern period, in which people from northern Europe tended to go to Rome in winter to avoid the "bad air" of summer, was already becoming a custom as early as the eighth century AD. ${ }^{33}$

The third and final stage in the spread of malaria in Italy was its advance to northern Italy. Vitruvius and Strabo state that the Po delta region, around Ravenna in northeastern Italy, was healthy about 2,000 years ago. ${ }^{34}$ This was evidently regarded as an unusual state of affairs for a marshy region. It cannot be attributed to any failure of malaria itself to reach the area, since the constant movements of merchants, administrators, soldiers and slaves during the Roman Empire would have spread malarial parasites within their bodies all over Europe. Nor was there a shortage of mosquitoes, since Roman authors such as Sidonius Apollinaris explicitly mention the mosquitoes of Ravenna. ${ }^{35}$ However, only certain anthropophilic species of mosquito are effective vectors of malaria. The most likely inference is that the mosquitoes of Ravenna in antiquity were not efficient vectors of the disease. Endemic malaria became possible in this region only during the medieval period, when a new anthropophilic species of mosquito, Anopheles sacharovi, colonized the coasts of northeastern Italy. The spread of malaria in Italy did not happen suddenly. It took at least 1500 years, from $c .500 \mathrm{BC}$ to $c .1000 \mathrm{AD}$. The hypothesis that this process depended on the spread of certain types of mosquito is highly plausible, just as speciation in the A. gambiae complex played an important role in the spread of malaria in tropical Africa, as Mario Coluzzi has argued. ${ }^{36}$ It has already been noted that Bruce-Chwatt and de Zulueta believed that $P$. vivax and $P$. malariae were present in Mediterranean Europe before

\footnotetext{
${ }^{31}$ Marcus Porcius Cato, Origines, II.17; photographs of Graviscae in Sallares, op. cit., note 5 above, pp. 194-5.

${ }^{32}$ Asclepiades ap. Caelius Aurelianus, De morbis acutis, II.63-4; Galen, VII.435 and XVIIA.121-2, Opera omnia, ed. C Kühn, Leipzig, C Cnobloch, 1821-33.

${ }^{33} \mathrm{M}$ McCormick, Origins of the European economy: communications and commerce,
}

\footnotetext{
A. D. 300-900, Cambridge University Press, 2001, pp. $80-1$.

${ }^{34}$ Vitruvius, De architectura, I.4.11-12; Strabo, Geographia, V.1.7.213C.

${ }^{35}$ Sidonius Apollinaris, Epistulae, I.8.2.

${ }^{36} \mathrm{M}$ Coluzzi, 'The clay feet of the malaria giant and its African roots: hypotheses and inferences about origin, spread and control of Plasmodium falciparum', Parassitologia, 1999, 41: 277-83.
} 


\section{The Spread of Malaria to Southern Europe in Antiquity}

$P$. falciparum. However, all three of these species of human malaria seem to have been present together, according to the earliest available literary evidence for both Greece and Italy. Logically, the prior presence of $P$. vivax and $P$. malariae would have required the availability as vectors anyway of suitable anopheline mosquito species, which could equally well have been transmitting $P$. falciparum at the same time. ${ }^{37}$ All three were ready to move together simultaneously into new regions, but had to wait for their mosquito vectors to move first.

\section{The Infant Cemetery at Lugnano in Teverina, Umbria, Italy}

So far only the evidence of historical documentary sources has been considered. However, scientific evidence for the ancient spread of malaria is now starting to become available through research on ancient biomolecules. ${ }^{38}$ Between 1988 and 1992 David Soren and his colleagues (from the University of Arizona) excavated a fascinating archaeological site at Lugnano in Teverina, about seventy miles up the Tiber valley from Rome. One of the largest infant cemeteries found in Roman Italy, dating to $c .450 \mathrm{AD}$, was unearthed in the ruins of an abandoned Roman villa (see Figure 1 for the location). This site has yielded important new evidence for the spread of malaria. ${ }^{39}$

Infants rarely received proper burial in Roman times. Several features of the finds led the archaeologists to conclude that the infant deaths had been caused by a disease epidemic. All the burials occurred in a short period of time within one year, since joins between potsherds from different levels of the fill indicate that the cemetery represents a single archaeological stratum. The spatial distribution of the burials within the cemetery suggests the increasing activity of an epidemic during that period of time. Plant remains indicate that the time of year was the summer, the season when malaria (a temperature-dependent disease) was active in Italy in the past. ${ }^{40}$ The number of burials is larger than the number of young children in the adjacent town of Lugnano today. This gives an indication of the size of the adult female breeding population that gave birth to the infants $c .450 \mathrm{AD}$. A disease is required that was capable of sweeping throughout the entire population and infecting virtually all the pregnant women at the same time. Moreover 22 out of the 47 excavated infants were premature births, while most of the others were neonates. ${ }^{41}$ Consequently, a

\footnotetext{
${ }^{37}$ On the question of the refractoriness of modern tropical strains of $P$. falciparum to European mosquitoes, see Sallares, op. cit., note 5 above, pp. 33-6. Refractoriness was probably overcome in North Africa and the Near East in prehistory before $P$. falciparum had even reached southern Europe.

${ }^{38}$ R Miller, S Ikram, G J Armelagos, R Walker, W Harer, et al., 'Diagnosis of Plasmodium falciparum infections in mummies using the rapid manual ParaSight-F test', Trans. R. Soc. Trop. Med. Hyg., 1994, 88: 31-2; G Taylor, P Rutland, and T Molleson, 'A sensitive polymerase chain reaction method for the detection of Plasmodium species DNA in ancient human remains', Ancient Biomolecules, 1997, 1: 193-203; N Cerutti, A Marin, E Massa, and D Savoia,
}

\footnotetext{
'Immunological investigation of malaria and new perspectives in palaeopathological studies', Bolletino della Società Italiana di Biologia Sperimentale, 1999, 75 (3-4): 17-20.

${ }^{39} \mathrm{D}$ Soren, T Fenton, and W Birkby, 'The late Roman infant cemetery near Lugnano in Teverina, Italy: some implications', J. Paleopathol., 1995, 7: 13-42; D Soren, and N Soren (eds), A Roman villa and a late Roman infant cemetery: excavation at Poggio Gramignano, Lugnano in Teverina, Rome, "L’Erma" di Bretschneider, 1999, pp. 461-651.

${ }^{40}$ Sallares, op. cit., note 5 above, pp. $61-3$, on the seasonality of malaria in Italy.

${ }^{41}$ Unfortunately no corresponding adult cemetery has been discovered.
} 


\section{Robert Sallares, Abigail Bouwman and Cecilia Anderung}

disease is required which produces not only high death rates but also a high rate of miscarriages in pregnant women.

Falciparum malaria fits the bill. It causes intrauterine growth retardation, which is associated with neonatal mortality, in immune or semi-immune pregnant women in tropical countries where malaria is holoendemic today. ${ }^{42}$ However in the past it also produced a high rate of miscarriages in non-immune pregnant women in temperate or subtropical regions where it had an epidemic rather than an endemic presence. ${ }^{43}$ For example, a series of cases in the United States in the first half of the twentieth century yielded a foetus death rate of 60 per cent, while there were also numerous cases of miscarriages during the Monte Cassino epidemic in 1944, the last major malaria epidemic in modern Italian history, and similarly at Amritsar in India in the early twentieth century. ${ }^{44}$ There is evidence that maternal malaria increases susceptibility to malaria in infants in the first year of life. Maternal malaria in the last week of pregnancy is particularly associated with neonatal mortality. ${ }^{45}$

The archaeological site is situated 185 metres above sea level in gently undulating countryside about $3.5 \mathrm{~km}$ away from the river Tiber, which is visible from the site. River valleys were a prime location for malaria in Italy because river floods frequently created mosquito breeding sites when the floodwaters retreated leaving behind small pools. The vicinity of Orte, on the Tiber a few kilometres from Lugnano, was particularly vulnerable to flooding in the past. A local doctor, Angelo Sorgoni, described the pernicious symptoms of intermittent fevers among itinerant agricultural labourers around Narni, near Lugnano, in 1832. ${ }^{46}$ This confirms that the local environment of Lugnano is indeed highly favourable to malaria. Relying on these circumstantial arguments, the archaeologists proposed the hypothesis that the deaths of the Lugnano infants were caused by an epidemic of falciparum malaria during the summer of one year in the middle of the fifth century $\mathrm{AD} .^{47}$

\footnotetext{
${ }^{42} \mathrm{C}$ Shulman, T Marshall, E Dorman, J Bumer, FCutts, et al., 'Malaria in pregnancy: adverse effects on haemoglobin levels and birthweight in primigravidae and multigravidae', Trop. Med. Int. Health, 2001, 6: $770-8$.

${ }^{43}$ A Barbosa and B López Arjona, El paludismo en el primer año de la vida, Madrid, Sáez Hermanos, 1935, pp. 11-18.

${ }^{44} \mathrm{R}$ Torpin, 'Malaria complicating pregnancy', Am.J. Obstet. Gynecol., 1941, 41: 882-5; C A Gill, The genesis of epidemics and the natural history of disease: an introduction to the science of epidemiology based upon the study of epidemics of malaria, influenza, and plague, London, Baillière, Tindall and Cox, 1928, pp. 74-83.

${ }^{45} \mathrm{C}$ Luxemburger, R McGready, A Kham, L Morison, T Cho, et al. 'Effects of malaria during pregnancy on infant mortality in an area of low malaria transmission', Am. J. Epidemiol., 2001, 154: 459-65; M Cot, J Le Hesran, T Staalsoe, N Fievet,
}

\author{
L Hviid, and P Deloron, 'Maternally transmitted \\ antibodies to pregnancy-associated variant \\ antigens on the surface of erythrocytes infected \\ with Plasmodium falciparum: relation to child \\ susceptibility to malaria', Am. J. Epidemiol., 2003, \\ 157: 203-9. \\ ${ }^{46}$ A Sorgoni, 'Riflessioni sulla maggior forza, con \\ cui si sviluppano le febbri intermittenti ne' \\ marchegiani abitanti nel territorio di Narni a confronto \\ di quella minore forza colla quale si producono \\ negl'indigeni narniesi', Giornale Arcadico di Scienze, \\ Lettere ed Arti, 1832, 57: 12-21. \\ ${ }^{47}$ For general accounts of Umbria in late antiquity, \\ see G Binazzi (ed.), L'Umbria meridionale fra \\ tardo-antico ed altomedioevo, Perugia, Università \\ degli Studi, 1991; S Bocci, L'Umbria nel Bellum \\ Gothicum di Procopio, Studi pubblicati dall'Istituto \\ italiano per la storia antica, vol. 62, Rome, Istituto \\ italiano per la storia antica, 1996.
}




\section{The Spread of Malaria to Southern Europe in Antiquity}

\section{Direct Evidence for Falciparum Malaria}

This hypothesis was tested by attempting to extract $P$. falciparum DNA from bone samples from the infant skeletons. A fragment of $P$. falciparum ribosomal DNA was successfully amplified from two separate DNA extractions from the skeleton of burial no. 36, the oldest child found on the site (a female 2-3 years old at death). ${ }^{48}$ The fact that malarial DNA could be amplified by the polymerase chain reaction from such an old skeleton suggests a massive infection, since it is unlikely in practice that an asymptomatic infection with a low level of parasitaemia could be detected after such a long passage of time. Consequently it is likely that falciparum malaria did indeed cause the death of this particular child. The results prove that falciparum malaria was present and tend to confirm the archaeologists' hypothesis that it was the cause of the Lugnano epidemic. ${ }^{49}$ Although positive results were obtained from only one out of forty skeletons that were sampled, it should be noted that it is not in the nature of the epidemiology of falciparum malaria for it to occur sporadically. If environmental conditions were favourable for it to have been present at all, many people would have been infected. The low success rate can be safely attributed to poor DNA preservation in the bones. ${ }^{50}$ The significance of the Lugnano epidemic is that it shows that falciparum malaria and by inference its principal vector in central Italy, Anopheles labranchiae, had attained their maximum geographical distributions in that region by the middle of the fifth century AD. A. labranchiae occurred as far up the Tiber valley as Orte, near Lugnano, as recently as the Second World War. Further north it was replaced by A. atroparvus, a secondary vector. $^{51}$

Documentary evidence shows that in late antiquity malaria was frequently conceptualized as a demon. In fact the term abracadabra, used in magic, originated as a spell against semitertian fever recorded by the Roman author Quintus Serenus. ${ }^{52}$ There is a remarkable synthesis of modern science and ancient pagan rituals in the archaeological finds from Lugnano, since the feet and hands of the infant who has yielded some malarial DNA were weighted down with stones and tiles, presumably to prevent the demons of malaria from escaping and causing further devastation (Figure 2). The magical rituals attested at Lugnano

\footnotetext{
${ }^{48}$ For details of the methods used, see R Sallares and S Gomzi, 'Biomolecular archaeology of malaria', Ancient Biomolecules, 2001, 3: 195-213 (with EMBL/ Genbank accession nos. AJ426487-8 for the malaria sequences that were obtained).

${ }^{49}$ Determination of the sex of a sample of these infants (see also next footnote) indicated that the infant population had a fairly normal sex ratio (five female and four male). Consequently there is no question of selective exposure of female infants in this cemetery.

${ }^{50}$ Only nine out of fifteen of the Lugnano infants that were sampled yielded positive results for sex determination by the amelogenin sex determination system-infant bones cannot be sexed by morphological methods (for details of methods see R Sallares, S Gomzi, A Bouwman, C Anderung, and $\mathrm{T}$ Brown, 'Identification of a malaria epidemic in antiquity using ancient DNA', in K Robson Brown (ed.), Archaeological Sciences 1999. Proceedings of
}

the Archaeological Sciences Conference, University of Bristol, 1999, Oxford, Archaeopress [BAR S1111], 2003, pp. 120-5). This ratio is comparable to results from other ancient Mediterranean archaeological sites, e.g. M P Evison, 'Ancient DNA in Greece: problems and prospects', Journal of Radioanalytical and Nuclear Chemistry, 2001, 247: 673-8; C Vernesi, D Caramelli, S Carbonell i Sala, M Ubaldi, F Rollo, and B Chiarelli, 'Application of DNA sex tests to bone specimens from three Etruscan (VII-III century B.C.) archaeological sites', Ancient Biomolecules, 1999, 2: 295-305; M Cipollaro, G Di Bernardo, G Galano, U Galderisi, et al., 'Ancient DNA in human bone remains from Pompeii archaeological site', Biochemical and Biophysical Research

Communications, 1998, 247: 901-4.

${ }^{51}$ Sallares, op. cit., note 5 above, pp. 64-8.

${ }^{52}$ Quintus Serenus, Liber medicinalis, 51.935-940, op. cit., note 19 above. 


\section{Robert Sallares, Abigail Bouwman and Cecilia Anderung}

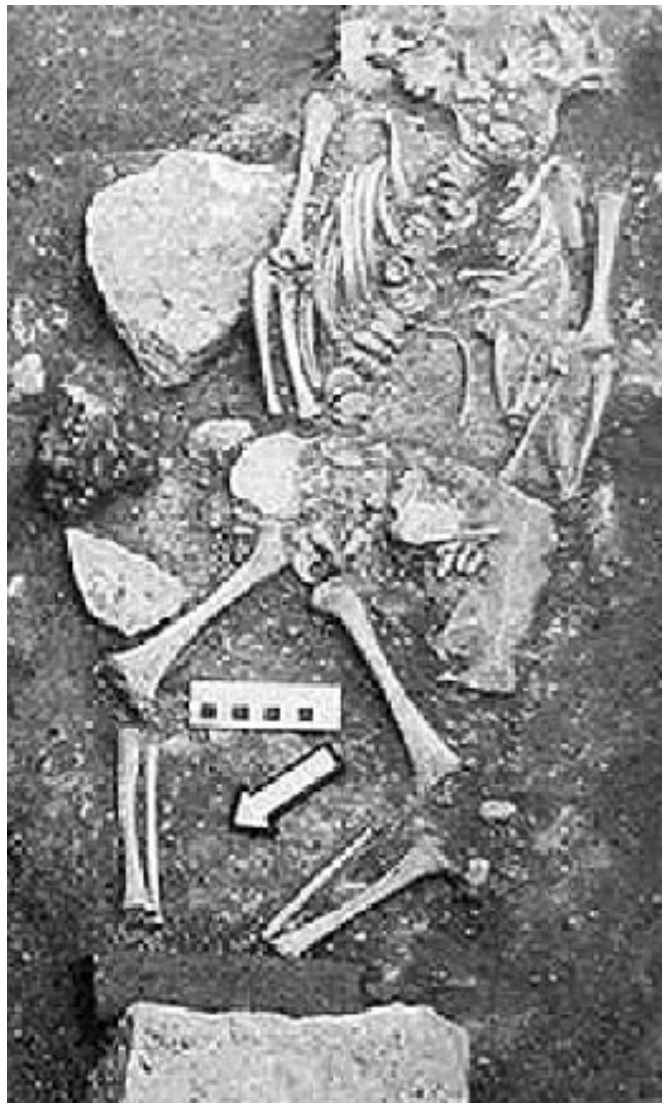

Figure 2: Infant burial no. 36, an inhumation burial, at the cemetery at Lugnano in Teverina.

provide archaeological evidence for the survival of pagan traditions connected to medicine in the countryside of central Italy in the fifth century AD despite the advance of Christianity. ${ }^{53}$

\section{Indirect Evidence for the Spread of Malaria}

The development of molecular population genetics over the last twenty years or so now provides a new, indirect, method of tracking the effects of malaria in the ancient Mediterranean world that was not available to previous generations of historians, by searching for evidence of human genetic mutations associated with resistance to malaria. The lack of haplotype diversity associated with most of the malaria resistance mutations found in modern Mediterranean populations suggests that they have evolved within the last few

\footnotetext{
${ }^{53}$ Literary evidence for the interaction of magic and religion in Umbria at this time has been discussed by G Bartocci, 'The cultural construction of the Western

conception of the realm of the sacred: co-existence,
} clash and interbreeding of magic and sacred thinking in fifth- and sixth-century Umbria', Anthropology and Medicine, 2000, 7: 373-88. 


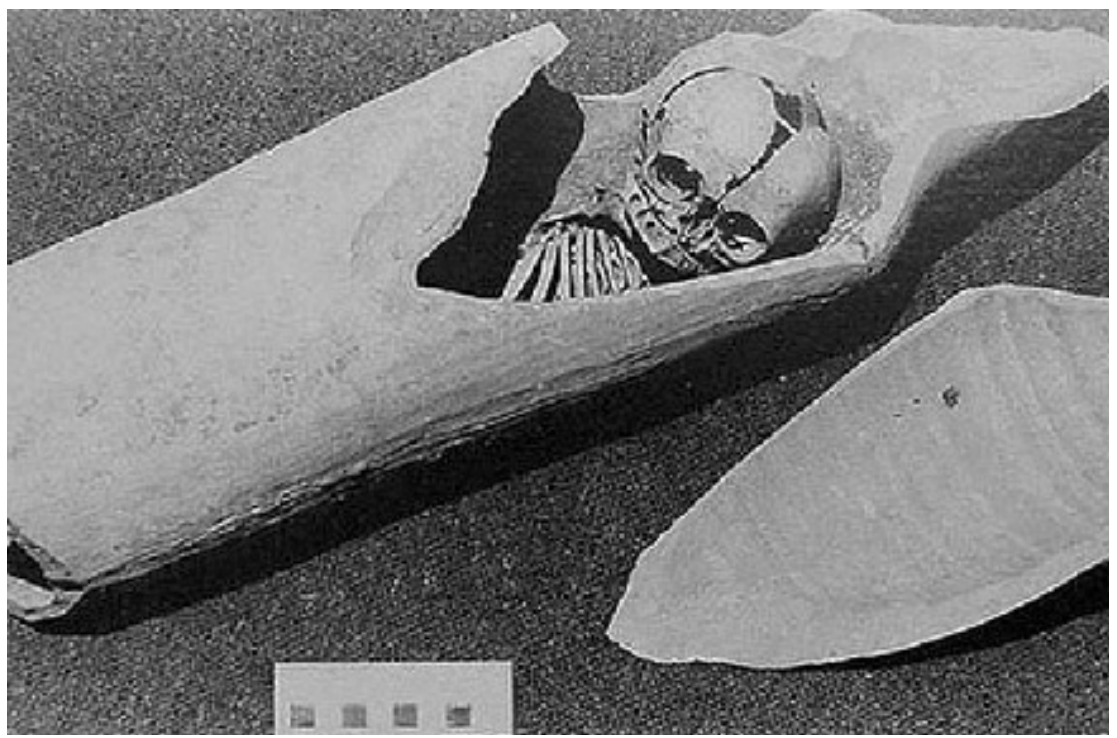

Figure 3: An example of an amphora burial from the infant cemetery at Lugnano in Teverina.

thousand years. ${ }^{54}$ This timescale is plausible, since it was too cold for malaria in Europe during the glacial periods. The most ancient osteological evidence for thalassaemia comes from the Near East, from a skeleton excavated at the now submerged village of Atlit Yam off the coast of Israel, dating to about 10,000 years ago. ${ }^{55}$ Various different sorts of evidence indicate that all the major types of inherited genetic resistance were present in the Mediterranean world by the time of the Roman Empire, about 2000 years ago. For example, the skeleton of a child with osteological modifications attributed to thalassaemia was excavated at Pisa in Italy in strata dated to the fifth to seventh centuries AD. ${ }^{56}$ A skeleton of a woman approximately seventeen years old, with morphological changes attributed to thalassaemia, was excavated at the Roman villa of Settefinestre, on the coast of Tuscany, dating to the third century AD. ${ }^{57}$ Similar evidence occurs earlier in the Greek world of Magna Graecia in southern Italy. Eleven skeletons with the porotic hyperostosis characteristic

${ }^{54}$ G O Tadmouri, N Garguier, J Demont, P Perrin, and A N Başak, 'History and origin of $\beta$-thalassaemia in Turkey: sequence haplotype diversity of $\beta$-globin genes', Human Biology, 2001, 73: 661-74; L Zahed, J Demont, R Bouhass, G Trabuchet, C Hänni, et al., 'Origin and history of the IVS-I-110 and codon-39 $\beta$-thalassemia mutations in the Lebanese population', Human Biology, 2002, 74: 837-47; S A Tishkoff, R Varkonyi, N Cahinhinan, S Abbes, G Argyropoulos, et al. 'Haplotype diversity and linkage disequilibrium at human G6PD: recent origin of alleles that confer malarial resistance', Science, 2001, 293: 455-62; L Luzzatto and R Notaro, 'Malaria: protecting against bad air', Science, 2001, 293: 442-3; P C Sabeti, D E Reich, J M Higgins, H Levine, D Richter, et al. 'Detecting recent positive selection in the human genome from haplotype structure', Nature, 2002, 419: 832-7.

${ }^{55}$ I Hershkovitz, B Rothschild, B Latimer,

O Dutour, E Léonetti, C Greenwald, et al. 'Possible congenital haemolytic anemia in prehistoric coastal inhabitants of Israel', Am. J. Phys. Anthropol., 1991, 85: 7-13, on the skeleton Homo 25.

${ }^{56} \mathrm{G}$ Baggieri and F Mallegni, 'Morphopathology of some osseous alterations of thalassic nature', Paleopathology Newsletter, 2001, 116: 10-16.

${ }^{57} \mathrm{~F}$ Mallegni and G Fornaciari, 'Le ossa umane', in A Ricci (ed.), Settefinestre: una villa schiavistica nell'Etruria romana, 3 vols, Modena, Panini, 1985, vol. 2, pp. 275-7, on skeleton no. 26.203 . 


\section{Robert Sallares, Abigail Bouwman and Cecilia Anderung}

of thalassaemia (presumably all homozygotes) were excavated in the Pantanello necropolis at the Greek colony of Metapontum, dating to the fourth and fifth centuries BC. ${ }^{58}$ This suggests that the Greek colonists had a significant population frequency of thalassaemia mutations and by inference a population history of contact with endemic falciparum malaria before the inhabitants of Latium and Etruria in western central Italy, around Rome, came into contact with it. Grmek examined seven terracotta statuettes from Smyrna in Asia Minor, dating to the Hellenistic period, which have "swollen faces with hypertrophied zygomatic arches and symmetrical protuberances on the fronto-parietal parts of the skull", with the base of the nose crushed. He concluded that these figurines are classic illustrations of homozygous thalassaemia. ${ }^{59}$

The sickle-cell trait was also present by Roman times. The skeleton of an approximately twenty-year-old man with porotic hyperostosis was excavated on the island of Failaka in the Persian Gulf. The bones were radiocarbon dated to $2130 \pm 80$ BP. Scanning-electron microscopy of the bones directly revealed fossilized erythrocytes with the characteristic sickle shape.$^{60}$ Research in experimental archaeology has confirmed that it is possible for human red blood cells to leave a recognizable print on archaeological materials. ${ }^{61}$ Today haemoglobin $S$ occurs with a frequency of about 2 per cent in some Mediterranean populations. Haplotype analysis has demonstrated that the sickle-cell trait in Sicily, northern Greece, and western Arabia is in linkage disequilibrium with the Benin haplotype in western central Africa. ${ }^{62}$ This constitutes direct evidence for gene flow linked to human migration from central Africa to Mediterranean Europe in historical times. The Failaka individual might have been a descendant of a Macedonian soldier from northern Greece with the Benin haplotype. Alternatively he might have been one of the local inhabitants, since there is molecular evidence for an independent origin of the sickle-cell trait in India and eastern Arabia, with a different haplotype association. The Indian variant of homozygous sickle-cell disease displays a mild clinical phenotype, associated with high levels of foetal haemoglobin which inhibits sickling. ${ }^{63}$ This could explain how the Failaka individual survived to adulthood.

To complete this picture some biomolecular evidence is now available for glucose-6phosphate dehydrogenase (G6PD) deficiency, the third major type of human genetic mutation commonly occurring in Mediterranean populations which confers some resistance to malaria. G6PD deficiency is caused by any one of about 140 different mutations or combinations of mutations that affect the functioning of a gene that plays a critical role in a biochemical pathway for removing oxidants that would otherwise damage erythrocytes. ${ }^{64}$

${ }^{58} \mathrm{~J}$ C Carter, The chora of Metaponto: the necropoleis, 2 vols, Austin, University of Texas Press, 1998, vol. 2, pp. 527-9, 553-6.

${ }^{59}$ Grmek, op. cit., note 21 above, p. 275 ; M Grmek and D Gourevitch, Les maladies dans l'art antique, Paris, Fayard, 1998, pp. 223-5.

${ }^{60} \mathrm{G}$ Maat and M Baig, 'Scanning electron microscopy of fossilized sickle-cells', Int. J. Anthropol., 1990, 5: 271-6; G Maat, 'Bone preservation, decay and its related conditions in ancient human bones from Kuwait', Int. J. Osteoarchaeol., 1993, 3: 77-86.

${ }^{61} \mathrm{P}$ Hortolà, 'Red blood cell haemotaphonomy of experimental human bloodstains on techno- prehistoric lithic raw materials', J. Archaeol. Sci., 2002, 29: 733-9.

${ }^{62}$ A Ragusa, M Lombardo, G Sortino, T Lombardo, $\mathrm{R} L \mathrm{~N}$ Nagel, and D Labie, ' $\beta$ ' gene in Sicily is in linkage disequilibrium with the Benin haplotype: implications for gene flow', Am. J. Hematol., 1988, 27: $139-41$.

${ }^{63}$ A Kulozik, J Wainscoat, G Serjeant, B Kar, B Al-Awamy, et al., 'Geographical survey of $\beta^{\mathrm{S}}$-globin gene haplotypes: evidence for an independent Asian origin of the sickle-cell mutation', Am.J.Hum. Genet., 1986, 39: 239-44

${ }^{64} \mathrm{~A}$ list of G6PD mutations is given by E Beutler and T J Vulliamy, 'Haematologically important 


\section{The Spread of Malaria to Southern Europe in Antiquity}

Such damage shortens the life span of red blood cells, causing premature phagocytosis or apoptosis, before malarial parasites inside the cell have completed their development. ${ }^{65}$ The large number of mutations, differential inactivation arising from the gene's location on the $\mathrm{X}$ chromosome, and other unknown factors, produce a wide range of expressions of G6PD deficiency in homozygous and heterozygous females and hemizygous males. ${ }^{66}$

The Lugnano infants were screened for the presence of the two commonest G6PD mutations in Mediterranean populations. ${ }^{67}$ None of those skeletons from which human DNA could be extracted yielded any evidence for the $844 \mathrm{G} \rightarrow \mathrm{C}$ mutation in exon 8 of the G6PD gene (the asymptomatic Seattle variant), but one infant (burial no. 22) tested positive for the $563 \mathrm{C} \rightarrow$ T mutation in exon 6 (G6PD Med variant). This mutation, the most frequent variant in Mediterranean populations, accounts for about 61 per cent of cases of G6PD deficiency in mainland Italy. ${ }^{68}$ It is associated with severe deficiency, potentially fatal neonatal jaundice in infants, and favism in older children. The disease favism was not formally described in medical literature until $1856 .{ }^{69}$ However, the taboo on eating broad beans (ingestion of which precipitates favism in some G6PD deficient individuals) among the followers of Pythagoras in antiquity is probably an ancient reference to it, as Grmek argued, even if Elinor Lieber's suggestion that "the Pythagorean community was primarily designed for the benefit of persons handicapped by favism" is rather speculative. ${ }^{70}$ The sex of the infant at Lugnano was determined as male by the amelogenin sex determination system. It is uncertain whether the G6PD Med variant actually provides any protection against malaria to male hemizygotes (as well as female heterozygotes). These experimental results confirm that G6PD deficiency, like thalassaemia and the sickle-cell trait, was already spreading in Mediterranean Europe during the time of the Roman Empire, presumably as a human evolutionary response to the spread of malaria.

It is generally thought that each individual mutation for traits such as thalassaemia and G6PD deficiency evolved only once and was then spread by human migration at a regional

mutations: glucose-6-phosphate dehydrogenase', Blood Cells, Molecules, and Diseases, 2002, 28: 93-103.

${ }^{65}$ M Cappadoro, G Giribaldi, E O’Brien, F Turrini, F Mannu, et al. 'Early phagocytosis of glucose-6phosphate dehydrogenase (G6PD)-deficient erythrocytes parasitized by Plasmodium falciparum may explain malaria protection in G6PD deficiency', Blood, 1998, 92: 2527-34; K Lang, B Roll, S Myssina, M Schittenhelm, H Scheel-Walter, et al., 'Enhanced erythrocyte apoptosis in sickle cell anaemia, thalassaemia and glucose-6-phosphate dehydrogenase deficiency', Cellular and Physiological Biochemistry, 2002, 12: 365-72.

${ }^{66}$ Y Abdulrazzaq, R Micallef, M Qureshi, A Dawodu, I Ahmed, et al., 'Diversity in expression of glucose-6-phosphate dehydrogenase deficiency in females', Clinical Genetics, 1999, 55: 13-19.

${ }^{67}$ For details of the methods used, see Sallares, et al., op. cit., note 50 above. See also A Bouwman and T Brown, 'Comparison between silica-based methods for the extraction of DNA from human bones from 18th to mid-19th century London', Ancient Biomolecules, 2002, 4: 173-8. For other work on the G6PD gene in degraded materials, see H Liu, X Huang, Y Zhang, $\mathrm{H}$ Ye, A Hamidi, et al. 'Archival fixed histologic and cytologic specimens including stained and unstained materials are amenable to RT-PCR', Diagn. Mol. Pathol., 2002, 11: 222-7.

${ }^{68}$ F Martinez di Montemuros, C Dotti, D Tavazzi, G Fiorelli, and M Cappellini, 'Molecular heterogeneity of glucose-6-phosphate dehydrogenase (G6PD) variants in Italy', Haematologica, 1997, 82: 440-6.

${ }^{69}$ A Minà La Grua, Memoria sopra l'itterizia e su le malattie ordinarie dei contadini di Castelbuono, Palermo, Vrizi, 1856.

${ }^{70}$ Grmek, op. cit., note 21 above, pp. $210-44$; E Lieber, 'The Pythagorean community as a sheltered environment for the handicapped', in $\mathrm{H}$ Karplus (ed.), International symposium on society, medicine and law (Jerusalem March 1972), Amsterdam, Elsevier, 1973, pp. 33-41, on p. 36. 


\section{Robert Sallares, Abigail Bouwman and Cecilia Anderung}

level, since human populations in each part of the world where malaria occurs or occurred in the past have their own distinctive mutations which do not occur elsewhere, and most of the mutations exist in the context of restricted haplotype diversity. For example, linkage disequilibrium with a silent mutation at nucleotide 1311 in exon 11 of the G6PD gene suggests that the G6PD Med variant probably evolved only once in the Mediterranean region and was then spread by human migrations around the Mediterranean from a single point of origin, although it did have a second quite separate point of origin in India lacking the association with the exon 11 mutation. ${ }^{71}$ One of the two most frequent $\beta$-thalassaemia mutations in Mediterranean populations today, the $B+\operatorname{IVS} n t 110$ mutation $(G \rightarrow A)$, which occurs in areas of Greek colonization in Italy, attains its highest frequencies today in eastern Mediterranean countries. It is very common in Greece, and is also associated with a high level of haplotype diversity in Turkey. ${ }^{72}$ Consequently, Italian scientists suggested that this particular mutation originated in Greece or Anatolia and was spread westwards to Italy by Greek colonization from the eighth century BC onwards. ${ }^{73}$ This hypothesis implies that falciparum malaria became an important agent of natural selection on human populations in the eastern Mediterranean before it became important in Italy. (If, for the sake of argument, the Greek colonists in southern Italy had not experienced falciparum malaria in their homeland of Greece before migrating, they should have evolved their own distinctive mutations afterwards when they encountered it later on in Italy, on the principle that each region evolves its own mutations.) This hypothesis is also congruent with the ancient literary evidence discussed earlier which suggests that the classical Greeks were familiar with falciparum malaria before the people of central Italy had experienced its effects.

The second common $\beta$-thalassaemia mutation in Mediterranean populations today, the CD39 mutation, has a quite different geographical distribution, concentrated in areas of Phoenician colonization in the western Mediterranean. Although it has been suggested that it evolved in the Levant and was spread from there to the western Mediterranean by the Phoenicians, ${ }^{74}$ its present distribution is almost entirely western. It achieves its highest level of associated haplotype diversity by genetic recombination in North Africa. ${ }^{75}$ Consequently it now seems more probable that the CD39 mutation actually evolved in North Africa, rather than the Levant, and was then spread northwards to Sardinia, Sicily and Spain by Phoenician colonization from North Africa during the first millennium BC. North Africa is the main centre of abundance today and the presumed main Ice Age refuge of the mosquito species Anopheles labranchiae, the most important vector of malaria in Italy in recent times.

\footnotetext{
${ }^{71} \mathrm{G}$ Gaetani and A Ferraris, 'Biochemistry of G6PD deficiency and molecular genetics of G6PD variants in Italy', in L S Greene and ME Danubio (eds), Adaptation to malaria: the interaction of biology and culture, Amsterdam, Gordon and Breach, 1997, pp. 9-31, on p. 20. J V Day, Indo-European origins: the anthropological evidence, Washington, DC,

Institute for the Study of Man, 2001, pp. 287-9, discusses the hypothesis of Eugene Giles that G6PD deficiency and the taboo on beans arose among the Proto-Indo-Europeans.

${ }^{72}$ Tadmouri, et al., op. cit., note 54 above.

${ }^{73}$ A Cao, M Gossens, and M Pirastu,

' $\beta$-thalassaemia mutations in Mediterranean
}

populations', Br. J. Haematology, 1989, 71: 309-12. Earlier discussions by medical historians and palaeopathologists (e.g. Grmek, op. cit., note 21 above, pp. 254-64) did not employ the evidence of DNA sequence data, which was not yet available.

${ }^{74}$ Cao, et al., op. cit., note 73 above.

${ }^{75}$ P Perrin, R Bouhassa, L Mselli, N Garguier, $\mathrm{V}$ Nigon, et al. 'Diversity of sequence haplotypes associated with $\beta$-thalassaemia mutations in Algeria: implications for their origin', Gene, 1998, 213: 169-77. 


\section{The Spread of Malaria to Southern Europe in Antiquity}

Adding up all this evidence, a picture emerges of two quite separate routes whereby malaria itself, its vector mosquitoes, and the associated human genetic mutations which give some degree of resistance to malaria, reached southern Europe in the past. One route passed from Tunisia in North Africa, via Sicily and Sardinia, to Italy. The second route commenced in the eastern Mediterranean and led from the Levant or Anatolia to Greece and then on to Italy. Previous scholarly literature generally speaks of malaria in Italy and in Greece in the same breath, without considering the possibility that malaria had different histories in these two countries. However, we have just seen that there is some evidence that falciparum malaria became an important agent of natural selection on human populations in the eastern Mediterranean before it became an important agent in mainland Italy.

\section{Role of Different Species of Mosquito}

Such a situation can be explained if it is remembered that the most important vectors of malaria in the western Mediterranean and the eastern Mediterranean were two different species of mosquito, A. labranchiae and A. sacharovi respectively, both members of the A. maculipennis complex. ${ }^{76}$ Not only are they different species, but they also have different geographical distributions and origins. A. labranchiae, the most important vector in central and southern Italy, originated in North Africa. It is a non-diapausing species of mosquito which remains active throughout the year and indeed breeds all the year round in North Africa, but cannot do so in mainland Italy. It had to stay inside houses or man-made animal shelters to survive the winter in southern Europe. ${ }^{77}$ In contrast A. sacharovi, the most important vector of malaria in Greece, tends to hibernate, a useful habit for surviving southern European winters. The Near East, the centre of its geographical distribution today, was presumably its refuge during the glacial periods.

The hypothesis is proposed here that A. sacharovi spread from the Near East to Greece (together with other Near Eastern vectors such as A. superpictus) a considerable time before A. labranchiae spread from North Africa to mainland Italy. As a result, there was intense malaria in some parts of Greece and the Near East before there was intense malaria in Italy. Consequently some of the most important malaria resistance mutations in Mediterranean populations probably evolved in the eastern Mediterranean in prehistory and were then spread westwards to Italy by Greek migrations in the eighth century BC. At about the same time Phoenician activity in the western Mediterranean opened up the second route, from North Africa to Italy. Although there were humans on Sardinia as early as c. $20000 \mathrm{BP}$, the spread of falciparum malaria to Sardinia was probably a result of Phoenician colonization. ${ }^{78}$ There was a considerable Phoenician presence not only on the coast but in the interior of Sardinia in the seventh century BC, with archaeological evidence for trade with the Etruscans, followed by a Carthaginian occupation from North Africa. ${ }^{79}$ The two routes

\footnotetext{
${ }^{76} \mathrm{C}$ Ramsdale and $\mathrm{K}$ Snow, 'Distribution of the genus Anopheles in Europe', Eur. Mosq. Bull., 2000, 7: $1-26$.

${ }^{77} \mathrm{~W}$ Horsfall, Mosquitoes: their bionomics and relation to disease, New York, Ross, 1955, pp. 94, 103, 107.

${ }^{78} \mathrm{P}$ Sondaar, 'Palaeolithic Sardinians: palaeontological evidence and methods', in M Balmuth
}

and R Tykot (eds), Sardinian and Aegean chronology: towards the resolution of relative and absolute dating in the Mediterranean, Oxford, Oxbow, 1998, pp. 45-51.

${ }^{79}$ S Moscati, Italia punica, Milan, Bompiani, 1986, pp. 150-2, 181. 


\section{Robert Sallares, Abigail Bouwman and Cecilia Anderung}

interacted in Sicily, the scene of both Phoenician and Greek colonization, where both of the two major $\beta$-thalassaemia mutations attain high frequencies. ${ }^{80}$ However, despite the availability of these two routes of travel, these mutations did not actually reach very high frequencies in Latium and Tuscany in central Italy because these areas were not directly colonized by the Greeks or Phoenicians. ${ }^{81}$ Subsequently, the Benin haplotype of the sicklecell trait travelled with migrants (slaves?) from central Africa, probably exploiting the two routes, since it occurs in some human populations in both the western and the eastern Mediterranean. This hypothesis integrates, firstly, the molecular evidence for the origin and distribution of human genetic mutations giving resistance to malaria; secondly, data on the behaviour, origin and distribution of the mosquito vectors; and, thirdly, the historical documentary evidence for the late spread of falciparum malaria in central Italy and its earlier presence in Greece.

The gradual spread of malaria in mainland Italy clearly occurred in historical times. The final step in this process did not happen until the medieval period, when endemic malaria emerged in the Po delta region of northeastern Italy, presumably as a result of the arrival of A. sacharovi, the dominant vector in recent times in that region. ${ }^{82}$ The spread of malaria to northeastern Italy occurred at a time when Ravenna and the emerging commercial centre of Venice were closely associated with the Byzantine Empire, as McCormick has pointed out. ${ }^{83}$ It is significant that it was the predominantly eastern Mediterranean A. sacharovi, rather than the western Mediterranean A. labranchiae, which became dominant in northeastern Italy.

The chronology of the spread of malaria in mainland Italy is reasonably clear. However, the chronology of its earlier spread in the eastern Mediterranean remains very uncertain. Before the texts of the Hippocratic Corpus begin to appear in the fifth century BC there is a lack of relevant literary sources. Furthermore, malaria itself does not cause any unambiguous morphological lesions on human bones, and no biomolecular evidence is currently available from Greece. Mirko Grmek and Danielle Gourevitch interpreted depictions of Heracles slaying the multi-headed serpent of Hydra on Corinthian pottery dating to the period c.630-570 $\mathrm{BC}$ as a reference to attempts to drain the malarial marshes of Lerna in the Argolid. ${ }^{84}$ This is quite plausible, but once again it only sets a terminus ante quem. ${ }^{85}$ The fact that the Greeks who founded colonies in the south of Italy from the eighth century BC onwards carried with them the commonest eastern Mediterranean $\beta$-thalassaemia mutation indicates that falciparum malaria was having severe effects in at least some parts of Greece by then. Beyond that point, investigation of porotic hyperostosis on human skeletal remains from archaeological sites is probably still the most promising approach to malaria in the prehistory of Greece, as argued by $\mathrm{J}$ Lawrence Angel. ${ }^{86}$

${ }^{80}$ G Schilirò, E Mirabile, R Testa,

G Russo-Mancuso, and S Dibenedetto, 'Presence of haemoglobinopathies in Sicily: a historic perspective', Am. J. Med. Genet., 1997, 69: 200-6.

${ }^{81}$ This is the explanation of the problem posed by Bruce-Chwatt and de Zulueta, op. cit., note 3 above, p. 15 .

${ }^{82}$ Sallares, op. cit., note 5 above, pp. $78-85$.

${ }^{83}$ M McCormick, 'The imperial edge: Italo-Byzantine identity, movement and integration, AD 650-950', in H Ahrweiler and A Laiou (eds), Studies on the internal diaspora of the Byzantine Empire,
Washington, DC, Dumbarton Oaks, 1998, pp. 17-52, on pp. 25-31.

${ }^{84}$ Grmek and Gourevitch, op. cit., note 59 above, pp. 97-9.

${ }^{85} \mathrm{~J}$ L Angel, 'Porotic hyperostosis or osteoporosis symmetrica', in D Brothwell and A Sandison (eds), Diseases in antiquity, Springfield, IL, C C Thomas, 1967, pp. 378-89, argued that there was malaria at Lerna in the Middle Bronze Age.

${ }^{86} \mathrm{~J}$ L Angel, 'Porotic hyperostosis, anemias, malarias, and marshes in the prehistoric eastern Mediterranean', Science, 1966, 153: 760-3. 